\title{
Repercussions of melatonin on the risk of breast cancer: a systematic review and meta-analysis
}

\author{
(D) Eduardo Carvalho de Arruda Veiga ${ }^{1}$ \\ (iD) Ricardo Simões ${ }^{1}$ \\ (iD) Vitor E Valenti ${ }^{2}$ \\ (iD) Jose Cipolla-Neto \\ (iD) Luiz Carlos Abreu ${ }^{4}$ \\ (D) Ernane Pedro Matos Barros ${ }^{4}$ \\ (D) Isabel Cristina Esposito Sorpreso ${ }^{1}$ \\ (D) Maria Candido P. Baracat ${ }^{1}$ \\ (iD) Edmund C Baracat ${ }^{1}$ \\ (iD) Jose Maria Soares Junior ${ }^{1}$
}

1. Discipline of Gynecology, Department of Obstetrics and Gynecology, Hospital das Clínicas, USP Medical School; São Paulo, Brasil
2. Post-graduation Program in Physical Therapy, State University of São Paulo (UNESP); Presidente Prudente, São Paulo, Brasil
3. Discipline of Neurosciences, Institute of Biological Sciences, University of São Paulo; São Paulo, Brasil 3. Discipline of Neurosciences, Institute of Biological Sciences, University of São Paulo; São Paulo, Brasil
4. Discipline of design and scientific writing - Faculty of Medicine of ABC; São Paulo, Brasil

http://dx.doi.org/10.1590/1806-9282.65.5.699

\section{SUMMARY}

Breast Cancer is common in women, but its etiology is not yet fully understood. Several factors may contribute to its genesis, such as genetics, lifestyle, and the environment. Melatonin may be involved in the process of breast cancer. Therefore, the aim of this study is to evaluate the influence of the levels of melatonin on breast cancer through a systematic review and meta-analysis. We performed a systematic review according to PRISMA recommendations. The primary databases MEDLINE, Embase, and Cochrane were consulted. There was no restriction on the year of publication and language. Data of systematic reviews from April 2017 to September to 2017 were analyzed. The meta-analysis was conducted using RevMan 5.3 software provided by the Cochrane Collaboration. From a total of 570 articles, 9 manuscripts were included in this review. They analy onzed women with breast cancer and control patients, of which 10\% and $90 \%$ were in the reproductive period and after menopause, respectively. The lowest level of melatonin was found in approximately 55\% of studies with breast cancer in post-menopause. The metanalyses of the studies demonstrated low levels of melatonin in breast cancer patients ( $n=963)$ compared with control patients $(n=1332)$, with a mean difference between the studies of -3.54 (Cl-6.01, -7.06). Another difference found was in the comparison between smoking patients, with an average difference between 1.80 [0.97-2.63]. Our data suggest that low levels of melatonin might be a risk factor for breast cancer.

KEYWORDS: Melatonin. Breast Neoplasms. Review. Risk factors. Meta-Analysis.

\section{INTRODUCTION}

The pineal gland is an endocrine organ that, among other functions, produces the melatonin hormone. Its production reaches its maximum at night and is regulated by the biological clock (suprachiasmatic nucleus) ${ }^{1,2}$. In humans, melatonin secretion increases during darkness hours and peaks between 2 and 4 a.m. with a subsequent gradual decrease during the rest of the night ${ }^{1,2}$. Disturbances on the melatonin production may have consequences on the organism and influence cancer genesis and growth ${ }^{3}$.

The mechanisms of melatonin action are generally through receptors (MT1 and MT2). MT1 is associated with the G receptor protease family, and MT2 is related to the hydrolysis of phosphoinositide and 
calcium $^{4}$. After the action of receptors, the intracellular signaling of melatonin involves the calmodulin, which in turn activates transcription factors, such as NFAT (Nuclear factor of activated T-cells). This transcription factor regulates the immune system and influences tumor growth as well as cell cycle genes ${ }^{5}$. This system is also implicated in breast cancer ${ }^{6}$. In addition, melatonin interplays with estrogen signaling pathways: a) interferes in estrogen synthesis by the reducing the gonadotropin action ${ }^{7} ; b$ ) disrupts the activation of estradiol receptors on breast tumors; c) regulates the enzymes involved in the biosynthesis of estrogens in other tissues (selective estrogen enzyme modulator). Those mechanisms may justify the protective effect of melatonin on tumor growth.

Studies in vitro ${ }^{8}$ and in vivo ${ }^{9}$ showed that melatonin is a potent antioxidant modulator that may prevent DNA damage and control tumor growth. Another function of melatonin is the destabilization of levels of HIF-1alpha (Hypoxia-inducible factor 1-alpha) that increases the reactive oxygen species induced by hypoxia and angiogenesis. Therefore, melatonin protects from potential damage through this mechanism and decreases the expression of VEGF in tumor ${ }^{10}$.

Breast cancer (BC) is one of the most common malignancies and the first cause of cancer-related mortality among women ${ }^{11}$. However, the mechanism involved in the genesis of this tumor is not totally clear. Night-shift female workers have a significantly increased risk of $\mathrm{BC}$ compared to women with normal sleep duration ${ }^{12}$. The decrease in melatonin levels may be related to enhancing the $\mathrm{BC}$ incidence in night worker ${ }^{513}$. Therefore, the propose of our study is to evaluate if low levels of melatonin are related to breast cancer through systematic review and meta-analysis.

\section{METHODS}

A systematic review was carried out to evaluate whether melatonin levels are associated with breast cancer in women during the reproductive period and after menopause. This review was conducted according to the recommendations established by PRISMA (Preferred Reporting Items for Systematic Reviews and Meta-Analysis) ${ }^{14}$.

In the selection of the studies, only those which analyzed the levels of melatonin and its relationship with breast cancer in women during the reproduc- tive years (pre-) and after menopause (post), as well as studies that also had a control group, were included in our study. The retrieval of the relevant articles was conducted using the strategy described in Table 1 on Medline, Embase, and Cochrane primary databases and the search was completed in September 2017 without restricting the year of publication and language ${ }^{15}$. Studies, which did not provide access to the full text and duplicates were excluded from the analysiss. References related to the topic identified in the retrieved articles were also included.

Two researchers conducted the process of selecting the studies and the evaluation of the titles and abstracts with the ability to elaborate systematic reviews (E.C.V. and R.S.S.) independently and blindly, following the inclusion and exclusion criteria. The selected articles were critically evaluated to be included or not in the review. When there was disagreement over the selection of studies among the investigators, a third reviewer was consulted (J.M.S.J.). In order to analyze the methodological quality of the articles included, the New Castle Ottawa scale was used considering those with a score $>$ or equal to 9. The PICO was: $\mathrm{P}=$ patients with breast cancer; $\mathrm{I}=$ collected blood or urine for melatonin measurements; $\mathrm{C}=$ normal patients without cancer; $\mathrm{O}=$ correlation between levels of melatonin and breast cancer frequency.

The information obtained from the studies selected for the systematic review was set out in a table, and the following characteristics were described: author's name and year of publication, study design, case series, patient's age, melatonin collection method, melatonin level, and outcome. (Table 1). For the meta-analysis, RevMan version 5.3 (Cochrane Collaboration, Oxford, UK) ${ }^{25}$ calculated the relative risk of incidence of contralateral breast cancer and distant metastasis. The random effect model was used in the heterogeneity period. The inclusion criteria for the meta-analysis were the methodology of urine collection, with the detection of creatinine, women who were in menopause, and the homogeneity of the results.

\section{RESULTS}

The search, identification, and selection process are presented in Figure 1. From the search strategies elaborated, 25 papers were selected from 572 abstracts and tiles. Among those studies, nine were finally selected for inclusion in the systematic re- 
FIGURE 1: FLOWCHART FOR SELECTION OF STUDIES.

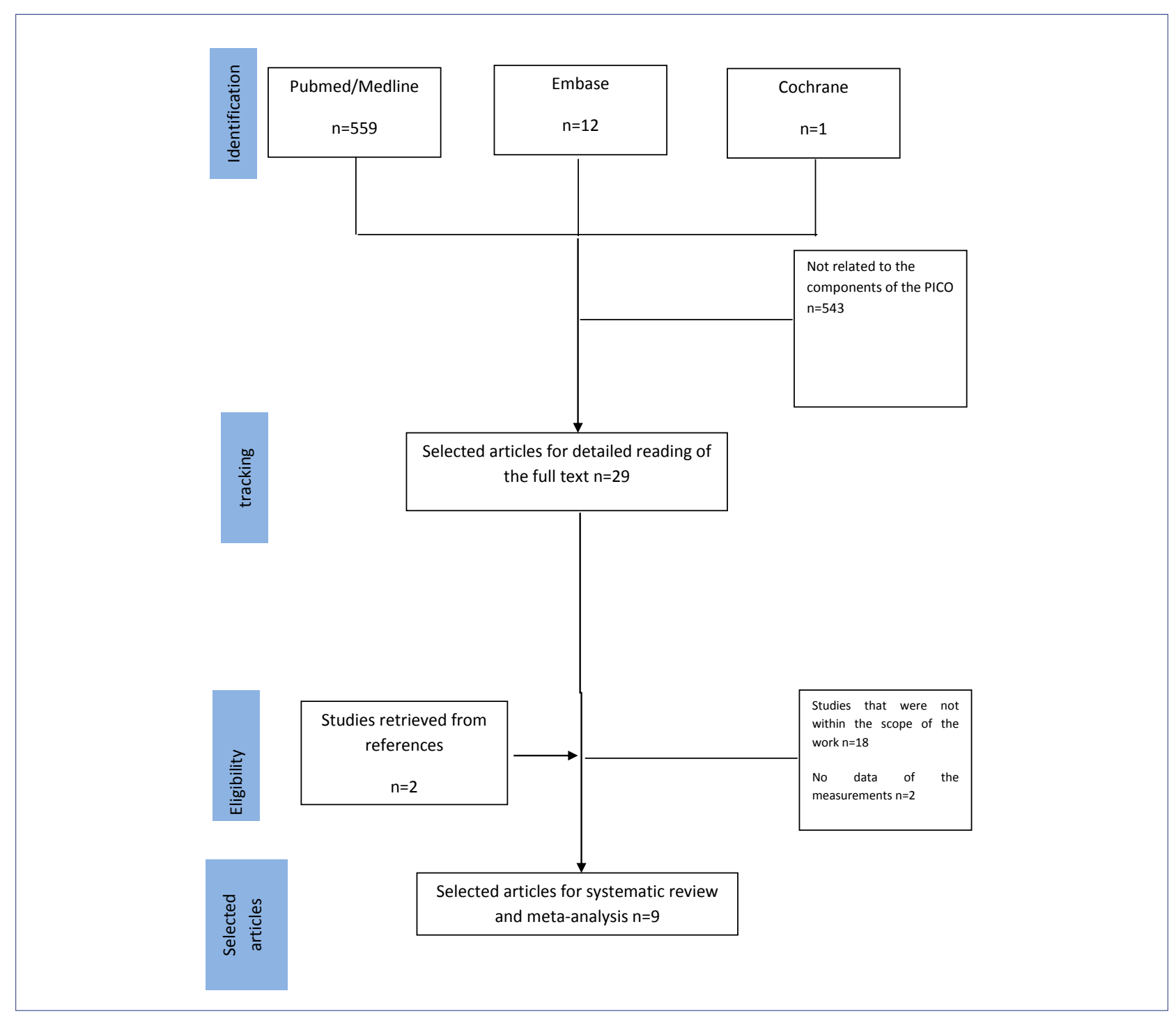

TABLE 1. AUTHOR AND YEAR OF THE STUDY, CASE STUDY, AGE OF PATIENTS, METHOD OF COLLECTION AND LEVEL OF MELATONIN.

\begin{tabular}{|c|c|c|c|c|c|c|}
\hline Authors & Study design & $\operatorname{groups}(n)^{\star}$ & Menopause & $\mathrm{Age}^{\star \star}$ & Methods & Outcome \\
\hline Bartsch et al.1981 & transversal & $\begin{array}{l}\mathrm{BC}(10) \\
\mathrm{C}(10)\end{array}$ & Post & $57.0 \pm 7.71$ & Urine & NS \\
\hline Danforth et al. 1985 & transversal & $\begin{array}{l}\text { BC (37) } \\
C(33)\end{array}$ & Pre & $34.0 \pm 7.21$ & Blood & NS \\
\hline Holdaway et al. 1991 & transversal & $\begin{array}{l}\mathrm{BC}(20) \\
\mathrm{C}(9)\end{array}$ & Pre & $40.4 \pm 6.03$ & Blood & NS \\
\hline Schernhamm et al 2005 & cohort, prospective & $\begin{array}{l}\text { BC(194) } \\
C(384)\end{array}$ & Pre & $44.4 \pm 2.8$ & Urine/Blood & Decreased \\
\hline Schernhammer et al. 2008 & cohort, prospective & $\begin{array}{l}\text { BC (178) } \\
\text { C (710) }\end{array}$ & Post & $52 \pm 24.04$ & Urine & Decreased \\
\hline Schernhammer et al. 2009 & cohort, prospective & $\begin{array}{l}\text { BC(357) } \\
C(533)\end{array}$ & Post & $67.2 \pm 6.7$ & Urine & Decreased \\
\hline Schernhamm et al 2010 & cohort, prospective & $\begin{array}{l}B C(180) \\
C(683)\end{array}$ & Pre & $43.4 \pm 4.3$ & Urine & Decreased \\
\hline Brown et al. 2015 & cohort, prospective & $\begin{array}{l}\text { BC(600) } \\
C(786)\end{array}$ & Pre & $48.9 \pm 30.5$ & Urine & NS \\
\hline Devore et al. 2016 & cohort, prospective & $\begin{array}{l}\text { BC (606) } \\
\text { C (799) }\end{array}$ & Post & $42.2 \pm 17.7$ & Urine & Decreased \\
\hline
\end{tabular}

${ }^{*} \mathrm{n}=$ number of patients; $\mathrm{BC}$ - breast cancer patient; $\mathrm{C}$ - control women; ${ }^{* *}$ mean \pm standard deviation; Decrease: indicates that melatonin levels in control patients are higher than melatonin levels in patients with breast cancer.NS - indicates that there were no differences between levels of melatonin in patients with breast cancer $x$ control patients. 
FIGURE 2. MECHANISMS OF MELATONIN ACTION IN BREAST CANCER CELLS.

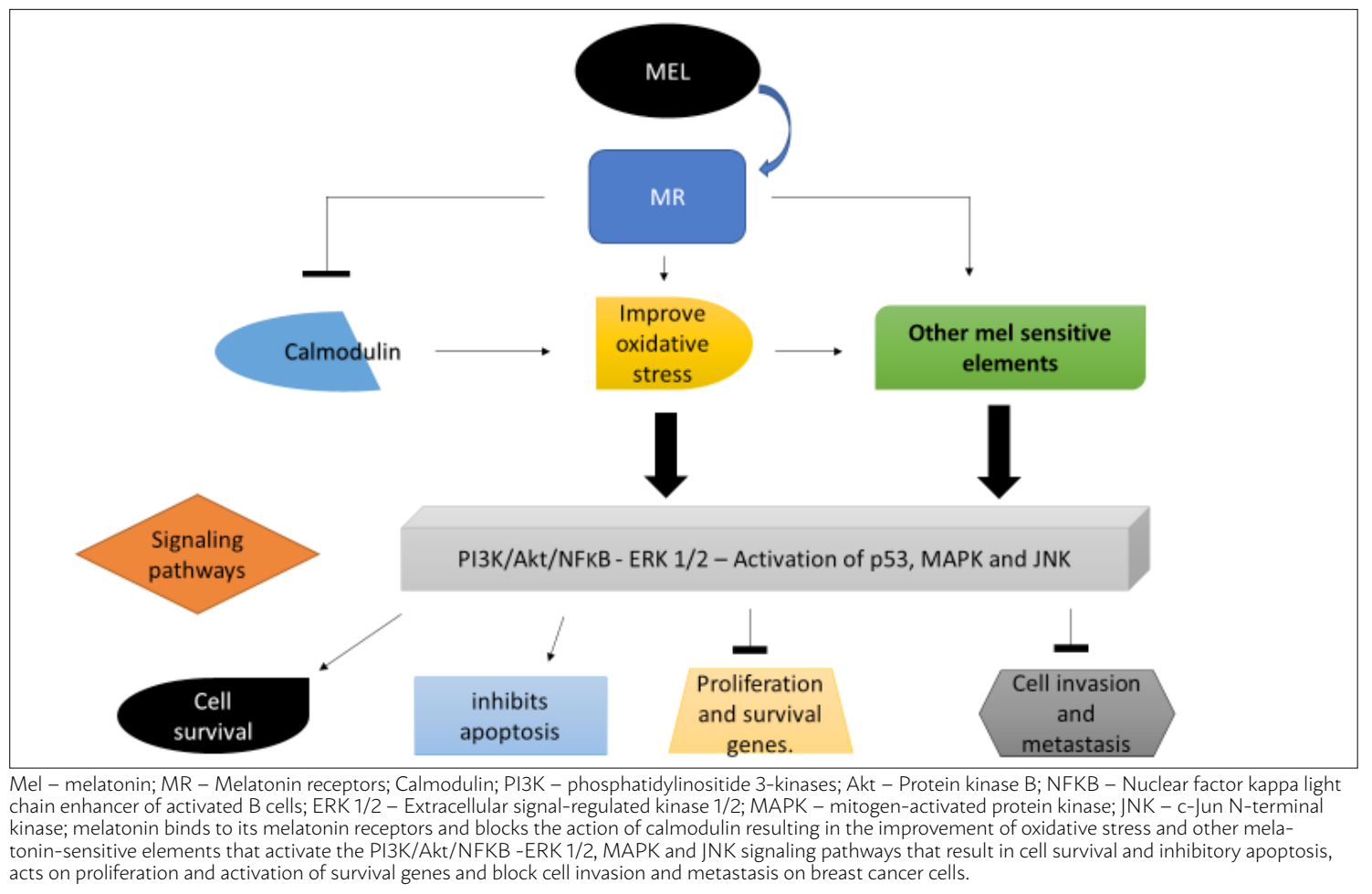

FIGURE 3. META-ANALYSIS OF MELATONIN LEVELS IN RELATION TO BREAST CANCER PATIENTS AND POST-MENOPAUSAL CONTROL PATIENTS.

\begin{tabular}{|c|c|c|c|c|c|c|c|c|c|}
\hline \multirow[b]{2}{*}{ Study or Subgroup } & \multicolumn{3}{|c|}{ Cancer de mama } & \multicolumn{3}{|c|}{ Controle } & \multicolumn{2}{|r|}{ Mean Difference } & \multirow{2}{*}{$\begin{array}{c}\text { Mean Difference } \\
\text { IV, Random, } 95 \% \mathrm{Cl}\end{array}$} \\
\hline & Mean & SD & Total & Mean & SD & Total & Weight & IV, Random, $95 \% \mathrm{Cl}$ & \\
\hline Devore et al. 2016 & 26.6 & 25.9 & 606 & 29.8 & 30.7 & 799 & $69.5 \%$ & $-3.20[-6.16,-0.24]$ & \\
\hline Schernhammer et al. 2009 & 24.5 & 29 & 357 & 28.8 & 39 & 533 & $30.5 \%$ & $-4.30[-8.77,0.17]$ & \\
\hline Total $(95 \% \mathrm{Cl})$ & & & 963 & & & 1332 & $100.0 \%$ & $-3.54[-6.01,-1.06]$ & \\
\hline \multicolumn{9}{|c|}{$\begin{array}{l}\text { Heterogeneity: } \mathrm{Tau}^{2}=0.00 ; \mathrm{Chi}^{2}=0.16, \mathrm{df}=1(\mathrm{P}=0.69) ; \mathrm{I}^{2}=0 \% \\
\text { Test for overall effect: } \mathrm{Z}=2.80(\mathrm{P}=0.005)\end{array}$} & $\begin{array}{cccc}-10 & -5 & 0 & 5 \\
\text { Cancer de mama } & \text { Controle }\end{array}$ \\
\hline
\end{tabular}

view ${ }^{16-24}$. The total number of women evaluated was 6.389, of whom 963 had breast cancer and 1332 did not. The majority of patients were post-menopausal (90\%), and only $10 \%$ were of reproductive age.

The age range was very heterogeneous: a) from 25-56 years old still in the reproductive period; b) from 45-80 years old post-menopausal. The levels of melatonin in the studies were measured through blood and mainly by urine. Although studies of Schernhammer et al. ${ }^{19}$ 2005, Brown et al. ${ }^{23}$, Devore et al. ${ }^{24}$ collected urine for 24 hours, the others measured melatonin from the first urine in the morning. Also, Schernhammmer et al. ${ }^{20}$, Schernhammer et al. ${ }^{21}$, Schernhammer et al. ${ }^{22}$ divided nocturnal melatonin secretion into four quartiles during the night, and the last one was the most representative because it shows peak levels of melatonin.
In all studies, only stage IV breast cancer was not included. A total of $55 \%$ of the studies (5/9) presented low melatonin levels in patients with breast cancer compared to the control group in the reproductive period ( $\mathrm{n}=2$ studies, 17, 22) and post-menopausal ( $\mathrm{n}=3,19-21)$ (Table 1).

The meta-analysis demonstrated that in the two studies analyzed, there was a significant difference in the melatonin means in breast cancer postmenopausal patients $(\mathrm{n}=963)$ and control patients ( $\mathrm{n}=1332$ ); the mean difference was -3.54 (CI: -6.01, -1.06) (Figure 2). Figure 3 shows the results of the meta-analysis in premenopause patients; the meta-analysis was in relation to body mass index, and the results refer to alcohol consumption per day (g/ day) among patients and melatonin levels in smoking patients. Other studies were not included in the me- 
ta-analysis because their standard deviations were very heterogeneous, making it impossible to reach a homogeneous result in a meta-analysis.

\section{DISCUSSION}

Breast cancer is still a challenge for medicine because the genesis of the tumor is still unknown ${ }^{26}$. Experimental studies (in vivo and in vitro) have been shown that melatonin may exert an anti-proliferation action that interferes in cancer risk ${ }^{27}$. the lLow levels of melatonin probably influence breast cancer risk.

Some studies had a few methodological problems. In the first studies ${ }^{16-18}$, the number of patients was meager for finding a statistical difference between breast cancer patients and the control group. Also, those studies measured melatonin directly from urine and not 6-sulfatoxymelatonin, which is the more stable metabolite of melatonin. Therefore, it may not reflect the exact amount produced because of the degradation of melatonin ${ }^{16-18}$. That is probably the explanation why they did not find any significant differences between breast cancer patientsand healthy ones.

The detection method improved a lot in recent years. The majority of studies that found low levels of melatonin used 6-sulfatoxymelatonin measurements and normalized by creatinine levels. This is probably the most accurate method for detecting the levels of this hormone ${ }^{26,27}$ because this metabolite is more stable than melatonin ${ }^{28}$. The studies that have found low levels of melatonin applied this method.

The estrogen hormone state is another problem, because estrogen levels may interfere with melatonin production and action ${ }^{11}$. Therefore, the phase of the menstrual cycle is important for comparison. This fact may explain the reasons why some studies did not find any differences during the reproductive period even studying a significant number of patients ${ }^{23}$.

Among the pathways of intracellular signaling, we can highlight the rupture of the calcium homeostasis produced by the inhibition of calmodulin, the improvement of oxidative stress, and the signaling cascade that leads to a lower rate of apoptosis. Among the proteins that are part of this pathway are the PI3K / Akt / NFkB pathway, the pathways involving the ERK $1 / 2$ proteins and the activation of p53, MAPK, and JNK. The results obtained are a higher rate of survival of healthy cells and inhibition of cell proliferation and their genes in addition to a lower rate of cell invasion in cells with breast cancer and a reduction in the angiogenesis of tumor cells $s^{11,29,30}$.

Regardless of the results, melatonin is considered a tumor inhibitor ${ }^{29}$. Also, the melatonin reduces the estrogen receptor in tumor ${ }^{\mathbf{s 2 4 , 2 8 , 3 1}}$ and interferes in the immune system, favoring the combat against breast neoplasia ${ }^{30}$. There are other melatonin mechanisms: a) it blocks estrogen receptors binding to DNA and transactivation functions ${ }^{32}$; b) it has anti-angiogenic and antioxidant actions (ref) and; c) it induces apoptosis in tumors ${ }^{31,32}$.

The clinical application of our data is on the night workers who are exposed to long periods of light and low levels of melatonin ${ }^{16,33}$. Therefore, this is a risk population for breast cancer due to the fact that their light/dark cycle is interrupted. Currently, night jobs are essential in hospitals, law enforcement, trade, and industry. There are also other risk factors, such as family history of cancer, use of hormone therapy,

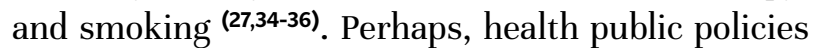
for evaluating melatonin levels or even taking melatonin supplementation might be necessary for preventing the risk of developing breast cancer. However, further studies are necessary to prove that this procedure would be beneficial for these patients.

Finally, our data suggested that a lower amount of melatonin may be a risk for breast cancer or at least, influences tumor growth.

\section{Acknowledgments}

This study was supported by grants from CAPES, FAPESP, and CNPq.

\section{Competing interests}

The authors declare that they have no competing interests.

\section{AUTHOR'S CONTRIBUTIONS}

1. ECAV - Made substantial contributions to the concept and design of the study and the definition of intellectual content, were involved in literature search, data analysis, statistical analysis, manuscript preparation, drafting the article or revising it critically for important intellectual content and giving final approval of the version to be published.

2. RS - Were involved in the literature search, data analysis, statistical analysis, and final approval of the version to be published. 
3. VEV - Were involved in the literature search, data analysis, statistical analysis, and final approval of the version to be published.

4. JCN - Made substantial contributions to the concept and design of the study and the definition of intellectual content, were involved in literature search, data analysis, statistical analysis, manuscript preparation, drafting the article or revising it critically for important intellectual content and giving final approval of the version to be published.

5. LCA - Made substantial contributions to the concept and design of the study and definition of intellectual content, were involved in literature search, data analysis, statistical analysis, manuscript preparation, drafting the article or revising it critically for important intellectual content and giving final approval of the version to be published.

6. EPMB - Were involved in the literature search, data analysis, statistical analysis and giving final approval of the version to be published.
7. ICES - Were involved in the literature search, manuscript preparation and final approval of the version to be published.

8. MCPB - Were involved in the literature search, data analysis, statistical analysis and giving final approval of the version to be published.

9. ECB - Made substantial contributions to the concept and design of the study and definition of intellectual content, were involved in literature search, data analysis, statistical analysis, manuscript preparation, drafting the article or revising it critically for important intellectual content and giving final approval of the version to be published.

10. JMSR - Made substantial contributions to the concept and design of the study and definition of intellectual content, were involved in literature search, data analysis, statistical analysis, manuscript preparation, drafting the article or revising it critically for important intellectual content and giving final approval of the version to be published.

\section{RESUMO}

O câncer de mama é comum em mulheres, mas sua etiologia ainda não é totalmente compreendida. Vários fatores podem contribuir para sua gênese, genética, estilo de vida e meio ambiente. A melatonina pode estar envolvida no processo de câncer de mama. Portanto, o objetivo deste estudo é avaliar a influência dos níveis de melatonina no câncer de mama por meio de uma revisão sistemática e meta-análise. Realizamos uma revisão sistemática de acordo com as recomendações do Prisma. Os principais bancos de dados, Medline, Embase e Cochrane, foram consultados. Não houve restrição quanto ao ano de publicação e idioma. Os dados de revisão sistemática obtidos de abril de 2017 a setembro a 2017 foram analisados. A meta-análise foi conduzida pelo programa RevMan 5.3 fornecido pela Cochrane Collaboration. De um total de 570 artigos, nove foram incluídos nesta revisão. As análises foram conduzidas em mulheres com câncer de mama e pacientes controle, dos quais 10\% e 90\% estavam no período reprodutivo e após a menopausa, respectivamente. O nível mais baixo de melatonina foi encontrado em aproximadamente $55 \%$ dos estudos com câncer de mama na pós-menopausa. As meta-análises de estudos demonstraram os baixos níveis de melatonina em doentes com câncer da mama ( $n=963)$, em comparação com os pacientes de controle $(n=1.332)$, sendo a diferença de médias entre os estudos da $-3,54(C l-6,01$, -1,06). Outra diferença é demonstrada nas comparações entre pacientes fumantes, sendo a diferença da média entre 1,80 [0,97-2,63]. Nossos dados sugerem que baixos níveis de melatonina podem ser um fator de risco para câncer de mama.

PALAVRAS-CHAVE: Melatonina. Neoplasias da mama. Revisão. Fatores de risco. Meta-análise.

\section{REFERENCES}

1. Brainard GC, Hanifin IP, Gresson JM, Byrne B, Glickman G, Gerner E, et al. Action spectrum for melatonin regulation in humans: evidence for a novel circadian photoreceptor. J Neurosci. 2001;21(16):6405-12.

2. Gamble KL, Berry R, Frank SJ, Young ME. Circadian clock control of endocrine factors. Nat Rev Endocrinol. 2014;10(8):466-75.

3. Cos S, Alvarez-García V, Gonz. ález A, Alonso-González C, Martinez-Campa C. Melatonin modulation of crosstalk among malignant epithelial, endothelial and adipose cells in breast cancer. Oncol Lett. 2014;8(2):487-92.

4. Becker-André M, Wiesenberg I, Schaeren-Wiemers N, André E, Missbach $M$, Saurat $J H$, et al. Pineal gland hormone melatonin binds and activates an orphan of the nuclear receptor superfamily. J Biol Chem. 1994;269(46):28531-4.
5. Zheng |, Fang F, Zeng X, Medler TR, Fiorillo AA, Clevenger CV. Negative cross talk between NFAT1 and Stat 5 signaling in breast cancer. Mol Endocrinol. 2011;25(12):2054-64.

6. Kaunisto A, Henry WS, Montaser-Kouhsari L, Jaminet SC, Oh EY, Zhao L, et al. NFAT1 promotes intratumoral neutrophil infiltration by regulating IL8 expression in breast cancer. Mol Oncol. 2015;9(6):1140-54.

7. $\mathrm{Xu}$ J, Huang L, Sun GP. Urinary 6-sulfatoxymelatonin level and breast cancer risk: systematic review and meta-analysis. Sci Rep. 2017;7(1):5353.

8. Tan DX, Hardeland R, Back K, Manchester LC, Alatorre-limenez MA, Reiter RJ. On the significance of an alternative pathway of melatonin synthesis via 5-metoxytryptamine: comparisons across species. | Pineal Res. 2016;61(1):27-40. 
9. Ferreira SG, Pelliciari-Garcia RA, Takahashi-Hyodo SA, Rodrigues AC, Amaral FG, Berra CM, et al. Effects of melatonin on DNA damage induced by cyclophosphamide in rats. Braz J Med Biol Res. 2013;46(3):278-86.

10. Park SY, Jang WJ, Yi EY, Jang JY, Jung Y, Jeong JW, et al. Melatonin suppresses tumor angiogenesis by inhibiting HIF-Talpha stabilization under hypoxia. J Pineal Res. 2010;48(2):178-84.

11. Luchetti F, Canonico B, Betti M, Arcangeletti M, Piolli F, Piroddi $M$, et al. Melatonin signaling and cell protection function. FASEB J. 2010;24(10):3603-24.

12. Samulin Erdem J, Skare $\varnothing$, Petersen- $\varnothing$ verleir $M$, Noto $\varnothing$, Lie JS, Reszka E, et al. Mechanisms of breast cancer in shift workers: DNA methylation in five core circadian genes in nurses working night shifts. J Cancer. 2017;8(15):2876-84.

13. Samulin Erdem J, Notø $H \varnothing$, Skare $\varnothing$, Lie JS, Petersen- $\varnothing$ verleir $M$, Reszka E, et al. Mechanisms of breast cancer risk in shift workers: association of telomere shortening with the duration and intensity of night work. Cancer Med. 2017;6(8):1988-97.

14. Moher D, Liberati A, Tetzlaff J, Altman DG; PRISMA Group. Preferred reporting items for systematic reviews and meta-analyses: the PRISMA statement. Int J Surg. 2010;8(5):336-41.

15. Bernardo WM, Nobre MR, Jatene FB. Evidence-based clinical practice. Part II: Searching evidence databases. Rev Assoc Med Bras. 2004;50(1):104-8.

16. Barstch $\mathrm{C}$, Barstch $H$, Jain $A H$, Laumas $K R$, Wetterberg L. Urinary melatonin levels in human breast cancer patients. J Neural Transm. 1981;52(4):281-94.

17. Danforth DN Jr, Tamarkin L, Mulvihill JJ, Bagley CS, Lippman ME. Plasma melatonin and the hormone-dependency of human breast cancer. I Clin Oncol. 1985;3(7):941-8.

18. Holdaway IM, Mason BH, Gibbs EE, Rajasoorya C, Hopkins KD. Seasonal chances in serum melatonin woman with previous breast cancer. $\mathrm{Br}$ ] Cancer. 1991;64(1):149-53.

19. Schernhamman ES, Hankinson SE. Urinary melatonin levels and breast cancer risk. J Nat Cancer Inst. 2005;97(14):1084-7.

20. Schernhamman ES, Berrino F, Krogh V, Secreto G, Micheli A, Venturelli $E$, et al. Urinary 6-sulfatoxymelatonin levels and risk of breast cancer in postmenopausal women. J Natl Cancer Inst. 2008;100(12):898-905.

21. Schernhammer ES, Hankinson SE. Urinary melatonin levels and postmenopausal breast cancer risk in the Nurses' Health Study cohort. Cancer Epidemiol Biomarkers Prev. 2009;18(1):74-9.

22. Schernhammer ES, Berrino F, Krogh V, Secreto G, Micheli A, Venturelli E, et al. Urinary 6-Sulphatoxymelatonin levels and risk of breast cancer in premenopausal women: the ORDET cohort. Cancer Epidemiol Biomarkers Prev. 2010;19(3):729-37.

23. Brown SB, Hankinson SE, Eliassen HA, Reeves KW, Qian J, Arcaro KF, et al.
Urinary melatonin concentration and the risk of breast cancer In Nurses' Health Study II. Am J Epidemiol. 2015;181(3):155-62.

24. Devore EE, Warner ET, Eliassen AH, Brown SB, Beck AH, Hankinson SE, et al. Urinary melatonin in relation to postmenopausal breast cancer risk according to melatonin 1 receptor status. Cancer Epidemiol Biomarkers Prev. 2017;26(3):413-9.

25. Higgins JPT, Altman DG. Assessing risk of bias in included studies. In: Higgins JPT, Green S, eds. Cochrane Handbook for Systematic Reviews of Interventions Version 5.0.1 (updated September 2008). The Cochrane Collaboration, 2008. Available from: www.cochrane-handbook.org.

26. Evans DG, Kesavan N, Lim Y, Gadde S, Hurley E, Massat N), et al. MRI breast screening in high-risk women: cancer detection and survival analysis. Breast Cancer Res Treat. 2014;145(3):663-72.

27. Conrad C, Götte M, Schlomann U, Roessler M, Pagenstecher A, Anderson $P$, et al. ADAM8 expression in breast cancer derived metastases: functional implications on MMP-9 expression and transendothelial migration in breast cancer cells. Int J Cancer. 2017;142(4):779-91.

28. Nagata C, Tamura T, Wada K, Konhishi K, Goto Y, Nagao Y, et al. Sleep duration, nightshift work, and the timing of meals and urinary levels of 8-isoprostane and 6-sulfatoxymelatonin in Japanese women. Chronobiol Int. 2017;34(9):1187-96.

29. Nooshinfar E, Bashash D, Safaroghli-Azar A, Bayati S, Rezaei-Tavirani M, Ghaffari SH, et al. Melatonin promotes ATO-induced apoptosis in MCF7 cells: proposing novel therapeutic potential for breast cancer. Biomed Pharmacother. 2016;83:456-65.

30. Proietti S, Cucina A, Reiter RJ, Bizzarri M. Molecular mechanisms of melatonin's inhibitory actions on breast cancer. Cell Mol Life Sci. 2013;70(12):2139-57.

31. Madaeva IM, Danusevich IN, Zhambalova RM, Kolesnikova LI. Melatonin in therapy of sleep disorders age-related estrogen deficiency. Zh Nevrol Psikhiatr Im S S Korsakova. 2017;117(5):81-4.

32. Ajith TA. Strategies used in the clinical trials of gene therapy for cancer. J Exp Ther Oncol. 2015;11(1):33-9.

33. Varea O, Garrido JJ, Dopazo A, Mendez P, Garcia-Segura LM, Wandosell F. Estradiol activates beta-catenin dependent transcription in neurons. PLoS One. 2009;4(4):e5153.

34. Boyko $Y$, Jennum P, Toft P. Sleep quality and circadian rhythm disruption in the intensive care unit: a review. Nat Sci Sleep. 2017;9:277-84.

35. Shin IS, Shin NR, Park JW, Jeon CM, Hong JM, Kwon OK, et al. Melatonin attenuates neutrophil inflammation and mucus secretion in cigarette smoke-induced chronic obstructive pulmonary diseases via the suppression of Erk-Sp1 signaling. J Pineal Res. 2015;58(1):50-60.

36. Harpsoe NG, Andersen LP, Gögenur I, Rosenberg J. Clinical pharmacokinetics of melatonin: a systematic review. Eur | Clin Pharmacol. 2015;71(8):901-9. 